\title{
Anorexigenic Hormones Leptin, Insulin, and $\alpha$-Melanocyte- Stimulating Hormone Directly Induce Neurotensin (NT) Gene Expression in Novel NT-Expressing Cell Models
}

\author{
Hong Cui, ${ }^{1}$ Fang Cai, ${ }^{1}$ and Denise D. Belsham ${ }^{1,2}$ \\ ${ }^{1}$ Department of Physiology, University of Toronto, and ${ }^{2}$ Departments of Obstetrics and Gynecology and Medicine, University of Toronto, and Division of \\ Cellular and Molecular Biology, Toronto General Hospital Research Institute, University Health Network, Toronto, Ontario, Canada M5S 1A8
}

\begin{abstract}
Neurotensin (NT) is implicated in the regulation of energy homeostasis, in addition to its many described physiological functions. NT is postulated to mediate, in part, the effects of leptin in the hypothalamus. We generated clonal, immortalized hypothalamic cell lines, $\mathrm{N}-39$ and $\mathrm{N}-36 / 1$, which are the first representative NT-expressing cell models available for the investigation of NT gene regulation and control mechanisms. The cell lines express the $\mathrm{Ob}-\mathrm{R}_{\mathrm{b}}$ leptin receptor neuropeptide $\mathrm{Y}$ (NPY)-Y1, Y2, Y4, Y5 receptors, melanocortin 4 receptor, insulin receptor, and the NT receptor. NT mRNA levels are induced by $\sim 1.5$-fold to twofold with leptin, insulin, and $\alpha$-melanocyte stimulating hormone treatments but not by NPY. Leptin-mediated induction of NT gene expression was biphasic at $10^{-11}$ and $10^{-7} \mathrm{M}$. The leptin responsive region was localized to within -381 to $-250 \mathrm{bp}$ of the $5^{\prime}$ regulatory region of the NT gene. Furthermore, we demonstrated direct leptin-mediated signal transducers and activators of transcription (STAT) binding to this region at $10^{-11} \mathrm{M}$, but not $10^{-7} \mathrm{M}$ leptin, in chromatin precipitation assays. Leptin-induced NT regulation was attenuated by dominant-negative STAT3 protein expression. These data support the hypothesis that NT may have a direct role in the neuroendocrine control of feeding and energy homeostasis.
\end{abstract}

Key words: neurotensin; hypothalamic neurons; leptin; $\alpha$-MSH; insulin; transcription

\section{Introduction}

Neurotensin (NT), originally isolated from the bovine hypothalamus (Carraway and Leeman, 1973), is widely distributed throughout the CNS and digestive tract (Carraway and Leeman, 1975). In the CNS, NT controls a number of physiological processes including feeding suppression, regulation of the circadian pacemaker, anti-psychotic-like action, anti-pain, regulation of body temperature, secretory stimulation of hypothalamic releasing hormones and anterior pituitary hormones, and neuromodulation of dopamine neurotransmission (Rostene and Alexander, 1997; Dobner et al., 2001; Meyer-Spasche et al., 2002; Remaury et al., 2002). The effects of NT are mediated by NT receptor 1 (NTR1) and NTR2 (Tyler-McMahon et al., 2000), whereas NTR3 is sortilin, a novel lysosomal sorting receptor (Mazella et al., 1998).

NT is also found within neurons of the hypothalamus, a region of the brain known to control feeding. Leptin is mainly secreted by adipocytes (Zhang et al., 1994), and circulating leptin acts on the hypothalamus to reduce food intake and increase energy expenditure (Schwartz et al., 1999). The two main

Received June 3, 2005; revised Aug. 19, 2005; accepted Aug. 26, 2005.

This work was supported by the Canadian Institutes for Health Research. D.D.B. holds a Canada Research Chair in Neuroendocrinology and is a Canada Foundation for Innovation Researcher. H.C. is supported by a Premier's Research Excellence Award to D.D.B.

Correspondence should be addressed to Dr. Denise D. Belsham, Department of Physiology, University of Toronto Medical Sciences Building 3247A, 1 King's College Circle, Toronto, Ontario, Canada M5S 1A8. E-mail: d.belsham@utoronto.ca.

DOI:10.1523/JNEUROSCI.2269-05.2005

Copyright $\odot 2005$ Society for Neuroscience $\quad$ 0270-6474/05/259497-10\$15.00/0 feeding-related neurons, proopiomelanocortin (POMC) and neuropeptide Y (NPY) neurons, are directly regulated by leptin in an opposing manner (Baskin et al., 1999a; Elias et al., 1999). Other potential targets of direct leptin signaling include galanin-expressing neurons, melanin-concentrating hormoneexpressing neurons, thyrotropin-releasing hormone (TRH)expressing neurons, and NT-expressing neurons (Sahu, 1998; Harris et al., 2001). NT neurons are responsive to leptin (Sahu, 1998; Elias et al., 2000; Richy et al., 2000). Evidence from in vivo studies in rats indicate that NT may modulate the central effects of leptin on feeding behavior (Beck et al., 1998; Sahu et al., 2001). Leptin receptors belong to the cytokine receptor superfamily (Tartaglia et al., 1995), and the active, long form $\left(\mathrm{ObR}_{\mathrm{b}}\right)$ is highly expressed within the hypothalamus (Lee et al., 1996). The $\mathrm{ObR}_{\mathrm{b}}$ is thought to mediate the effects of leptin through the Janus kinase (JAK)-signal transducers and activators of transcription (STAT) pathway (Ghilardi et al., 1996). However, the direct action of leptin in hypothalamic NT neurons and the concomitant signaling cascades involved are not yet defined. Additionally, no reports on the connection between insulin or $\alpha$-MSH signaling on the activation of NT neurons or NT gene expression are yet available.

Previous cell models have been used to study hormonal control of NT gene activation, such as PC12 pheochromocytoma cells (Harrison et al., 1995) and SK-N-SH neuroblastoma cells (Watters and Dorsa, 1998); however, these cell types are not likely representative of endogenous hypothalamic NT-expressing neurons, particularly those involved in feeding control (Beck et al., 1998; Sahu et al., 2001). To create a more appropriate model, we 
generated novel, clonal, hypothalamic neuronal cell models (Belsham et al., 2004). These cell lines express specific neuronal markers, including NT, and respond to an array of hormones resulting from the expression of functional receptor proteins. We analyzed hormonal responses within these NT cell lines and defined the molecular mechanisms involved in leptin-mediated regulation of NT gene expression. These cell models provide a novel tool to understand the direct control of NT neurons by hormones and neuromodulators involved in the regulation of feeding and energy homeostasis. In addition, the cell lines will allow analysis of endogenous leptin, insulin, and melanocortin-4 (MC4) receptor (MC4R) activation and signaling in representative hypothalamic neurons.

\section{Materials and Methods}

Cell immortalization and subcloning. The cell lines were generated using the method described previously (Belsham et al., 2004). Briefly, hypothalamii were harvested and dissected from mice at embryonic day 15 (E15), E17, and E18. The dissociated cell culture was then plated on culture dishes containing primary culture medium [DMEM, 10\% heatinactivated defined fetal bovine serum (FBS), 10\% heat-inactivated defined horse serum, $1 \%$ penicillin-streptomycin, and $20 \mathrm{~mm}$ D-glucose; Invitrogen, Carlsbad, CA]. Cells were infected with retrovirus containing the intact cDNA sequence for simian virus (SV40) large T antigen and neomycin resistance gene, harvested from confluent culture of $\psi 2$ cells [psitex cells (Brown et al., 1986)] producing a replication-defective, recombinant murine retrovirus. After $48 \mathrm{~h}$ in culture medium with the retrovirus, the cells were incubated with medium containing geneticin (G418) with a selective concentration $(400-600 \mu \mathrm{g} / \mathrm{ml}$ for initial selection; $250 \mu \mathrm{g} / \mathrm{ml}$ for cell maintenance). Mixed populations of hypothalamic cells were further subcloned by successive dilution of the trypsinized cell populations into 96-well plates. The optimal dilution allowed only one or two cells per well. Cell colonies were allowed to grow and then successively split into 24-well plates and then finally into $60 \mathrm{~mm}$ plates. Each cell line was purified three to four times. The NT-expressing cell lines were named N-36/1 and N-39.

Cell culture and treatment. Immortalized cell lines were grown in DMEM supplemented with 10\% FBS (Invitrogen), $20 \mathrm{~mm}$ glucose, and penicillin/streptomycin and maintained at $37^{\circ} \mathrm{C}$ with $5 \% \mathrm{CO}_{2}$. N-36/1 or $\mathrm{N}-39$ cells were grown overnight to $80-90 \%$ confluency, and the medium was replaced with serum-free DMEM 12-16 h before the beginning of the experiments. Cells were treated with leptin (Sigma-Aldrich, St. Louis, MO), NPY, $\alpha$-MSH (America Peptide, Sunnyvale, CA), and insulin (DB Biosciences, Mississauga, ON) for 4 or $8 \mathrm{~h}$. Vehicle-treated plates were used as a control at each time point indicated.

Reverse transcriptase-PCR. Total RNA from N-36/1 or N-39 cells was isolated by the guanidinium thiocyanate phenol chloroform extraction method (Chomczynski and Sacchi, 1987). First-strand cDNA was synthesized from 1 to $10 \mu \mathrm{g}$ of deoxyribonuclease I-treated RNA using SuperScript reverse transcriptase (RT) and random primers (Invitrogen) as described in the Superscript cDNA Synthesis kit (Invitrogen). The specificity of each amplification reaction was monitored in control reactions, in which amplification was performed on samples in which the RT was omitted (RT-). cDNA synthesis was followed by RNase H (180 U/ml; Invitrogen) digestion of RNA in a total volume of $20 \mu$ l. PCR amplifications were performed with $1.25 \mathrm{U}$ of Red Taq polymerase (Sigma) in a 50 $\mu \mathrm{l}$ reaction for 40 cycles $\left(1 \mathrm{~min}\right.$ at $94^{\circ} \mathrm{C}$, annealing temperature, and 1 min at $72^{\circ} \mathrm{C}$ ). Whenever possible, primers were designed from the mouse sequences in GenBank to span introns. The primers used for RT-PCR are listed in Table 1. These products were separated by $1.2 \%$ agarose gel electrophoresis, stained with $1 \mu \mathrm{g} / \mathrm{ml}$ ethidium bromide, and visualized under UV light. Identity was confirmed by sequencing (ACGT, Toronto, Ontario, Canada). All primers were made by ACGT.

Immunocytochemistry. The cells were cultured in glass slides to $60 \%$ confluency. The cultured cells were rinsed briefly in PBS, fixed with acetone:ethanol (1:1) for $10 \mathrm{~min}$ at $4^{\circ} \mathrm{C}$, permeabilized with $0.3 \%$ Triton $\mathrm{X}-100$ in PBS for $10 \mathrm{~min}$, and treated with 5\% normal goat serum that
Table 1. RT-PCR primer sequences

\begin{tabular}{|c|c|c|c|}
\hline Gene & Primer sequence & $\begin{array}{l}\text { Annealing } \\
\text { temperature }\left({ }^{\circ} \mathrm{C}\right)\end{array}$ & $\begin{array}{l}\text { Product size } \\
\text { (bp) }\end{array}$ \\
\hline NSE & $\begin{array}{l}\text { S: CTGATGCTGGAGTTGGATG } \\
\text { AS: CTTGGCTGTTCTCCAGGATAT }\end{array}$ & 60 & 391 \\
\hline $\mathrm{T}-\mathrm{Ag}$ & $\begin{array}{l}\text { S: AGAGGAATCTTTGCAGCTAA } \\
\text { AS: CTAAACACAGCATGACTCAA }\end{array}$ & 60 & 433 \\
\hline NT & $\begin{array}{l}\text { S: ATAGGAATGAACCTTCAGCTG } \\
\text { AS: GTAGGAGGCCCTCTTGAGTAT }\end{array}$ & 60 & 498 \\
\hline GFAP & $\begin{array}{l}\text { S: CTGAGGCTGGAGGCAGAGAAC } \\
\text { AS: CCTGTAGGTGGCGATCTCGAT }\end{array}$ & 57 & 621 \\
\hline $0 \mathrm{bR} \mathrm{b}_{\mathrm{b}}$ & $\begin{array}{l}\text { S: ATGACGCAGTGTACTGCTG } \\
\text { AS: GTGGCGAGTCAAGTGAACCT }\end{array}$ & 60 & 356 \\
\hline MC4R & $\begin{array}{l}\text { S: GGAAGATGAACTCCACCCACC } \\
\text { AS: GACGATGGTTTCCGACCCATT }\end{array}$ & 56 & 313 \\
\hline InsR & $\begin{array}{l}\text { S: GTGATACCAGAGCATAGGAG } \\
\text { AS: CTGTTCGGAACCTGATGAC }\end{array}$ & 60 & 480 \\
\hline NTR1 & $\begin{array}{l}\text { S: TGTTCAACTTCATCTGGGTGC } \\
\text { AS: ACGGTCAGTTTGTTGGCTA }\end{array}$ & 55 & 426 \\
\hline NPY-Y1 & $\begin{array}{l}\text { S: CTCTGGTTCTCATCGCTGTGGAACG } \\
\text { AS: ATTCGTTTGGTCTCACTGGACCTGT }\end{array}$ & 60 & 392 \\
\hline NPY-Y2 & $\begin{array}{l}\text { S: AAATGGCCCGGGGAGGAGAAGAG } \\
\text { AS: GTAGTGGTCACTTGCAGCTCCAGG }\end{array}$ & 60 & 157 \\
\hline NPY-Y4 & $\begin{array}{l}\text { S: GACTTGCTACCCATCCTCAT } \\
\text { AS: ATCACCACCGTCTCATCTA }\end{array}$ & 60 & 492 \\
\hline NPY-Y5 & $\begin{array}{l}\text { S: GGGCTCTATACATTCGTAAGTCTTCTTGGC } \\
\text { AS: CATGGCTTTGCCAAACATCCACTGATC }\end{array}$ & 60 & 203 \\
\hline
\end{tabular}

served as a blocking agent for nonspecific binding for $1 \mathrm{~h}$. Endogenous peroxidase activity was quenched by pretreatment with $0.3 \%$ hydrogen peroxide in PBS. Cells were then washed in PBS incubated at $4^{\circ} \mathrm{C}$ overnight with antibodies to neurofilament (NF) (1:200; Neomarkers, Fremont, CA) and NT (1:500; Immunostar, Hudson, WI). Cells were washed and incubated with biotinylated secondary antibody (Vector Laboratories, Burlingame, CA) for $60 \mathrm{~min}$, washed again, and incubated with the avidin biotin-peroxidase complex (Vector Laboratories) for an additional $60 \mathrm{~min}$. After final washing, the immunoreactive proteins were visualized with the addition of 3,3'diaminobenzidine (Sigma) for 2-10 min. Cells were counterstained with hematoxylin, dehydrated in graded ethanol, and cleared, and coverslips were applied.

Cell proliferation assay. The N-36/1 or N-39 cells $\left(6 \times 10^{4} / \mathrm{cm}^{2}\right)$ were cultured in a 24-well plastic culture plate in the DMEM supplemented with $10 \% \mathrm{FBS}$ at $37^{\circ} \mathrm{C}$ with $5 \% \mathrm{CO}_{2}$. At the indicated time points, the number of viable cells was assessed by the bioreduction of an MTT tetrazolium salt. The resulting blue formazan crystals were solubilized with dimethyl sulfoxide and quantified spectrophotometrically at $540 \mathrm{~nm}$.

Northern blot analysis. Northern blot analysis was performed as described previously (Belsham et al., 1996). Total RNA was isolated as described above. Ten micrograms of total RNA were size fractionated in $1 \%$ agarose-formaldehyde gels and transferred to GeneScreen membranes (NEN, Boston, MA) by capillary blotting (Maniatis et al., 1982). The filters were hybridized with mouse NT cDNA. Hybridization with mouse $\gamma$-actin cDNA was used to control for variations in gel loading and transfer efficiency. NT and $\gamma$-actin cDNA probes were generated by RTPCR. Prehybridization for $6-8 \mathrm{~h}$ and hybridization for $16 \mathrm{~h}$ were conducted in a $25 \%$ formamide hybridization buffer [ $1 \%$ BSA (w/v), $1 \mathrm{~mm}$ EDTA, $0.5 \mathrm{M} \mathrm{Na}_{2} \mathrm{HPO}_{4}, 5 \%$ SDS (w/v), and $25 \%$ formamide] at $55^{\circ} \mathrm{C}$. The cDNA probes were labeled using random hexamers and $\alpha$-[ $\left.{ }^{32} \mathrm{P}\right]$ deoxy-CTP $(6000 \mathrm{Ci} / \mathrm{mmol}$; NEN) incorporated with the Klenow fragment of DNA polymerase I. Blots were washed at high stringency $\left(55^{\circ} \mathrm{C} ; 0.5 \times \mathrm{SSC}, 0.1 \%\right.$ SDS) and exposed to Kodak film (Fisher Scientific, Nepean, Ontario, Canada) at $-70^{\circ} \mathrm{C}$ with intensifying screens for 4-48 h. Autoradiographs were scanned with an Epson 1260 Scanner (Epson, Long Beach, CA), and mRNA signals of NT and $\gamma$-actin were quantified by densitometry using the NIH Image program.

Quantitative RT-PCR. Total RNA was isolated, and reverse transcription was performed as described above. Quantitative real-time RT-PCR 
A
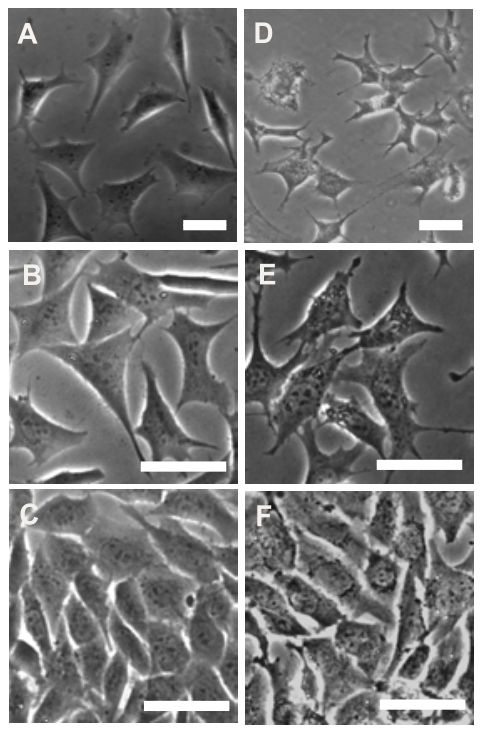

$\mathrm{N}-36 / 1$
B

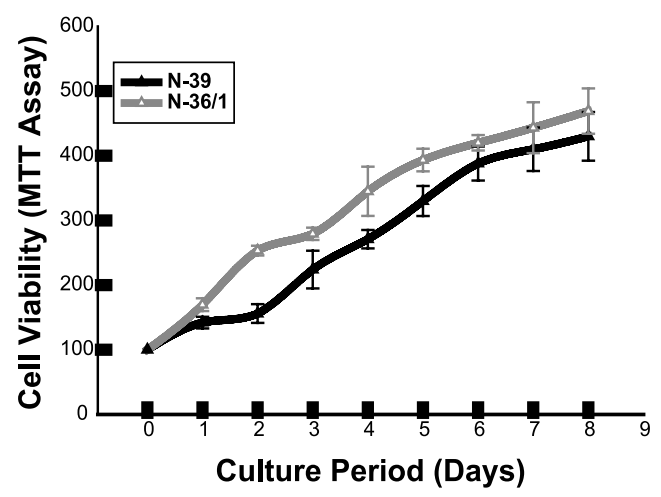

Figure 1. Morphology and growth characteristics of the two NT-expressing cell models N-36/1 and N-39.A, Phase-contrast micrographs of the immortalized mouse $\mathrm{N}-36 / 1$ and $\mathrm{N}-39$ neurons. $\boldsymbol{A}, \boldsymbol{B}, \boldsymbol{D}, \boldsymbol{E}$, Cells were cultured for $1 \mathrm{~d}$ after $\sim 30$ passages on plastic tissue culture plates in DMEM with 10\% FBS. C, $F$, Cells were cultured for $3 \mathrm{~d}$ in DMEM with 10\% FBS. Scale bar, 50 $\mu \mathrm{m}$. $B$, Cell growth curves of N-36/1 and N-39 neurons. Cells were plated on 24-well plates at a density of $5 \times 10^{4}$ cells/well in $1 \mathrm{ml}$ of DMEM with $10 \% \mathrm{FBS}$. The medium was changed every $2 \mathrm{~d}$. After attachment to the plate $(4 \mathrm{~h})$, the cells were counted by MTT assay as a control. At the indicated time points, the number of viable cells was assessed by MTT assay and expressed as a percentage relative to the control value. Data are expressed as mean $\pm \operatorname{SEM}(n=3)$.

was performed as described in the SYBR Green PCR Master Mix and PCR Protocol (Applied Biosystems, Foster City, CA). Briefly, cDNA was synthesized from $2.5 \mu \mathrm{g}$ of total RNA in a total volume of $10 \mu \mathrm{l}$, and $1 \mu \mathrm{l}$ of cDNA as a template was amplified with SYBR Green Master Mix (Applied Biosystems) and $300 \mathrm{~nm}$ primers in a $25 \mathrm{ml}$ reaction for 40 cycles ( 15 s at $95^{\circ} \mathrm{C} ; 1 \mathrm{~min}$ at $\left.60^{\circ} \mathrm{C}\right)$. The sequences of the primers for each gene are as follows: actin-SYBR-F, 5' -CTTCCCCACGCCATCTTG-3' (forward), actin-SYBR-R, 5' -CCCGTTCAGTCAGGATCTTCAT-3' (reverse); and NT-SYBR-436, 5' -GGCCTTTCAACACTGGGAGAT-3' (forward), NTSYBR-588, 5' -CTCTTGAGAATGTAGGGCCTTCTG-3' (reverse). All primers were designed using Primer Express software (Applied Biosystems) and synthesized by ACGT. Data were represented as $C_{\mathrm{t}}$ values, defined as the threshold cycle of PCR at which amplified product was first detected, and analyzed using ABI Prism 7000 SDS software package (Applied Biosystems). The copy number of amplified NT gene standardized to $\gamma$-actin using the $\delta$ - $C_{\mathrm{t}}$ method (ABI Prism 7700 Users Bulletin). The final fold differences in expression were relative to the corresponding treatment or vehicle treatment.

Plasmids and transient transfections. The full-length mouse NT 5' flanking gene plasmid was generated by PCR using the following primers on mouse genomic DNA: sense (-1523) 5'-CAGGCTTGCCAGTCAACCATC- $3^{\prime}$, antisense (+173) 5' ${ }^{\prime}$-AGACTCCAGGAGCTGAAAGCC- ${ }^{\prime}$. The PCR product was directly cloned into pDrive Cloning Vector (Qiagen, Valencia, CA). The deletion constructs were prepared by digestion with HindIII, which cut at nucleotide +173 within the $5^{\prime}$ untranslated region and BglII (-597), KpnI (-246), or NheI (+55) from the full-length - 1523 NT plasmid, followed by ligation into promoter-less vector, pGL2-enh (Promega, Madison, WI) with the appropriate enzyme. The additional deletion constructs were generated using PCR and the -1523 NT plasmid as the template. The primers used to generate the fragments were as follows: NTPm-487 (forward), 5'-ACGACGCGTTTTGAGACAACGAAGC-3' (MluI site is underlined); NTPm-409 (forward), 5'-ACGACGCGTGATTTCTCCCTAGAAC-3' (MluI site is underlined); and NTPm-HindIII (reverse), 5'-CGAGAAGCTTGTCGACGAATT-3' (HindIII site is underlined). All PCR fragments were subcloned into the pGL2-enh using the MluI to HindIII sites. All plasmid sequences were confirmed by sequencing
(ACGT). The six pGL2-enh-luciferase expressing constructs made were as follows: -1521NT-LUC (spanning -1521 to +173 ); -590NT-LUC (spanning -590 to +173 ); -459 NT-LUC (spanning -459 to +173 ); -381 NT-LUC (spanning -381 to +173 ); -250 NT-LUC (spanning -250 to +173 ); and +55 NT-LUC (spanning +55 to +173 , where +1 is the predicted site of transcription initiation).

Transfections were performed using the calcium phosphate precipitate method as described previously (Mellon et al., 1981). The cells were incubated for 14-16 h with DNA, followed by three PBS rinses. After a $2 \mathrm{~h}$ incubation, the cells were treated with or without $100 \mathrm{~nm}$ leptin and incubated for an additional $48 \mathrm{~h}$ before harvesting. Protein concentrations were determined using the Pierce BCA Protein Assay Reagent kit (Pierce, Rockford, IL). Luciferase assays were done as described previously (Belsham et al., 1998). The dominant-negative transfections were performed using LipofectAMINE2000 (Invitrogen) according to the instructions of the manufacture. The cells were incubated for $24 \mathrm{~h}$ with $2.5 \mu \mathrm{g}$ of pEFBOS (internal control), pWT-STAT3 (wild type of STAT3), or pDN-STAT3 (dominant-negative type of STAT3; kindly provided by Hiroshi Higuchi, Osaka University, Osaka, Japan) (Minami et al., 1996; Muraoka et al., 2003). Medium was then replaced with serum-free DMEM with $1 \%$ BSA for $2 \mathrm{~h}$, after which the cells were treated with or without $10^{-11} \mathrm{M}$ leptin and incubated for $4 \mathrm{~h}$ before RNA isolation. LipofectAMINE2000 was used in this case because the cells would not tolerate serum-free conditions after calcium phosphate exposure. Transfection efficiency was sufficient using either method, although LipofectAMINE2000 resulted in higher levels reaching $\sim 40-50 \%$.

Chromatin immunoprecipitation assay. ChIP assays were performed using previously described methodology (Barre et al., 2003, 2005). Cells were cross-linked with $1 \%$ formaldehyde for $10 \mathrm{~min}$ at room temperature and then washed with ice-cold PBS. The cell pellet was resuspended in cell lysis buffer [ $5 \mathrm{~mm}$ PIPES ( $\mathrm{KOH}$ ), pH 8.0, $85 \mathrm{~mm} \mathrm{KCl,} \mathrm{0.5 \%} \mathrm{NP-40]}$ containing protease inhibitors and incubated for $10 \mathrm{~min}$ on ice. The nuclei were lysed in the nuclear lysis buffer (50 mM Tris, pH 8.1, $10 \mathrm{~mm}$ EDTA, 1\% SDS) containing protease inhibitors and sonicated three times for $20 \mathrm{~s}$ each on ice. Supernatants were then recovered by centrifugation at 20,000 rpm for $10 \mathrm{~min}$ at $4^{\circ} \mathrm{C}$, diluted five times in dilution buffer (0.01\% SDS, 1.1\% Triton X-100, 1.2 mm EDTA, 16.7 mm Tris, pH $8.1,167 \mathrm{~mm} \mathrm{NaCl}$ ) plus protease inhibitors. The sample was precleared with $80 \mu \mathrm{l}$ of a $50 \%$ salmon sperm DNA/protein-G agarose slurry (Upstate Biotechnology, Lake Placid, NY) for $30 \mathrm{~min}$ at $4 \mathrm{C}$. Ten percent of the lysate was used as the input control (50-fold dilution). The rest of the supernatant was incubated with $2 \mu \mathrm{l}$ of anti-STAT3 antibody (Santa Cruz Biotechnology) at $4^{\circ} \mathrm{C}$ overnight, and then $60 \mu \mathrm{l}$ of a $50 \%$ salmon sperm DNA/protein-G agarose slurry was further added for $1 \mathrm{~h}$ at $4^{\circ} \mathrm{C}$. Immunoprecipitates were washed sequentially for 5 min each in low salt wash buffer (0.1\% SDS, 1\% Triton X-100, 2 mм EDTA, 20 mм Tris, pH $8.1,150 \mathrm{~mm} \mathrm{NaCl})$, high-salt wash buffer $(0.1 \%$ SDS, $1 \%$ Triton X-100, 2 mM EDTA, 20 mm Tris, pH 8.1, $500 \mathrm{~mm} \mathrm{NaCl}$ ), and $\mathrm{LiCl}$ wash buffer (0.25 M LiCl, 1\% NP-40, 1\% deoxycholate, 1 mm EDTA, 10 mm Tris, $\mathrm{pH}$ 8.0). Bead precipitates were then washed twice with TE buffer and eluted two times with elution buffer ( $\left.1 \% \mathrm{SDS}, 0.1 \mathrm{M} \mathrm{NaHCO}_{3}\right)$. The eluates were combined and incubated at $65^{\circ} \mathrm{C}$ for $5 \mathrm{~h}$ to reverse the formaldehyde cross-linking. The DNA was precipitated and dissolved in water and treated with proteinase $\mathrm{K}$ at $45^{\circ} \mathrm{C}$ for $2 \mathrm{~h}$. DNA was purified using Qiaquick spin columns (Qiagen) and eluted in $50 \mu \mathrm{l}$ of water. For PCR, $2 \mu \mathrm{l}$ of DNA was amplified for 35 cycles. The following primers were used: ACGACGCGTGATTTCTCCCTAGAAC (sense), GAGAGGTACTTCTGGTACCTTTTTCC (antisense) from -385 to $-234 \mathrm{bp}$ of the mouse NT/N promoter (STAT3 binding region). 
Statistical analysis. Data were analyzed using one-way ANOVA by GraphPad Prism (GraphPad Software, San Diego, CA), and statistical significance was determined using Tukey's multiple comparison tests or Student's $t$ test with $p<0.05$.

\section{Results}

Generation and characterization of hypothalamic cell models

The hypothalamus is recognized as the primary site of neuroendocrine control, which regulates physiological actions ranging from feeding behavior to reproduction. However, the lack of cell models from this region of the brain and the heterogeneity of cell types from the hypothalamus makes a single-cell model insufficient for detailed analysis of specific peptide receptor regulation. To generate an adequate model, primary hypothalamic cells from E15, E17, and E18 were mass immortalized through retroviral transfer of SV40 Large T antigen (T-Ag) (Belsham et al., 2004). Cells were analyzed for expression of neuron-specific enolase, $\mathrm{NF}$, and absence of glial-specific fibrillaryassociated protein (GFAP). The cells were then serially diluted to clone single-cell models of hypothalamic phenotypes. Initially, 16 unique cell lines were isolated with distinct cell morphology and phenotypic profiles of $>60$ cellular markers ((Belsham et al., 2004; our unpublished observations); however, none of the lines were shown to express NT. Additional subcloning of the mixed cell populations resulted in two cell lines, N-36/1 and N-39, with distinct neuro-

nal morphology (Fig. 1A) and expression of NT (Fig. 2A), as well as T-Ag and neuron-specific enolase (NSE), but not GFAP. The cells grow as a monolayer and exhibit contact inhibition when confluence is reached (Fig. 1A). Analysis of growth characteristics of the N-36/1 and N-39 cell lines were performed using standard cell proliferation assays over $8 \mathrm{~d}$. The cell lines demonstrate similar growth profiles with the same saturation density $(6 \times$ $\left.105 / \mathrm{cm}^{2}\right)$. The doubling time for the N-36/1 and N-39 neurons is $\sim 1.8$ and $2.3 \mathrm{~d}$, respectively (Fig. $1 B$ ). These cells have been continuously cultured for up to 40 passages and maintained in culture for over 3 years with stable expression of the cellular markers, including NT. The cell models have been phenotypically characterized for $\sim 70$ cell markers, and the two lines differ by $\sim 20 \%$, indicating they are unique cell types likely originating in distinct nuclei of the hypothalamus.

The levels of NT mRNA differ in each line, with N-36/1 expressing higher levels of NT (although NT is detectable by both Northern blot and RT-PCR in each line) (Fig. 2 B). The Northern blot reveals two mRNA species at 1.5 and $1.0 \mathrm{~kb}$ that arise from differential utilization of two consensus poly(A) tails and thus differ in the length of the $3^{\prime}$-untranslated region, as described previously (Rostene and Alexander, 1997). It has been found that the two mRNAs are present in approximately equal amounts in the brain. Immunocytochemistry with a specific antibody toward NT revealed immunoreactivity in the N-36/1 and N-39 cells, indicating NT protein expression (Fig. $3 E, G$ ). Staining was predominant around the cell nucleus and minimal throughout the

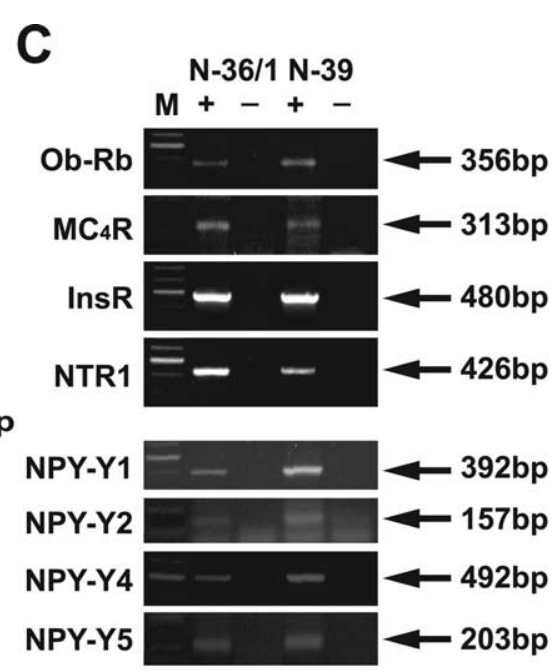

Actin 


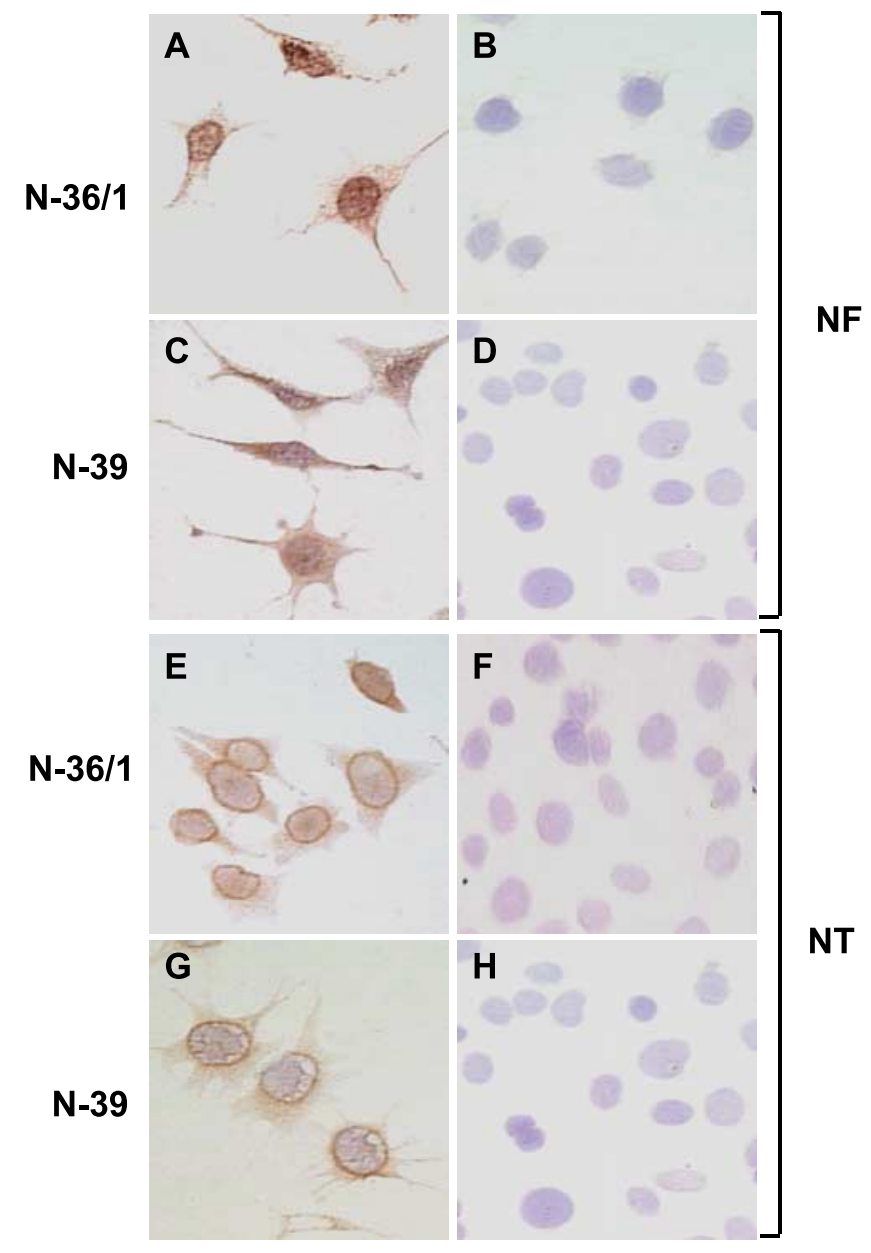

Figure 3. Immunocytochemistry of N-36/1 and N-39 neurons for NF and NT. A, C, Cells were cultured for $1 \mathrm{~d}$ on a glass slide in DMEM with $10 \% \mathrm{FBS}$ and analyzed with a specific NF antibody. $\boldsymbol{B}, \boldsymbol{D}$, Immunocytochemistry without NF primary antibody was used as a negative control. $\boldsymbol{E}, \boldsymbol{G}$, Cells were cultured for $1 \mathrm{~d}$ on a glass slide in DMEM with $10 \% \mathrm{FBS}$ and analyzed with a specific NT antibody. N-36/1 and N-39 cells were cultured for $1 \mathrm{~d}$ on a glass slide in DMEM with $10 \% \mathrm{FBS}$ and analyzed for NT (as above) but blocked with NT peptide, showing no nonspecific staining $(\boldsymbol{F}, \boldsymbol{H})$. Nuclei were stained with hematoxylin (blue). Magnification, $200 \times$.

gene, as indicated. We found that $10^{-9}$ and $10^{-8} \mathrm{M} \alpha$-MSH significantly increased NT mRNA at $4 \mathrm{~h}$ in the N-36/1 cells to 1.6and 1.7-fold, respectively (Fig. 4A). Similarly, NT gene expression in the N-39 cells increased $\sim 1.6$-fold after 4 and $8 \mathrm{~h}$ of $10^{-9}$ and $10^{-8} \mathrm{M} \alpha$-MSH treatment (Fig. $4 \mathrm{~B}$ ). In addition, $10^{-7} \mathrm{M}$ insulin increased NT 1.5-fold in the N-36/1 cell line at $4 \mathrm{~h}$ (Fig. $4 A$ ) and significantly increased NT mRNA levels in N-39 cells at both 4 and $8 \mathrm{~h}$ with $10^{-7}$ and $10^{-8} \mathrm{M}$ insulin. The increases in NT mRNA levels were found to be statistically significant $(p \leq 0.05)$ for the $\alpha-\mathrm{MSH}$ and insulin treatments. The $\alpha$-MSH and insulinstimulated NT mRNA levels declined over $8 \mathrm{~h}$ of treatment. Stimulation with NPY $\left(10^{-8}\right.$ and $\left.10^{-7} \mathrm{M}\right)$ did not significantly alter NT gene expression (Fig. $4 A, B$ ), although $10^{-7} \mathrm{M}$ NPY decreased NT expression slightly at $8 \mathrm{~h}$ in N-39 neurons (Fig. $4 B$ ), which may indicate that additional studies should be performed with an extended time course. Representative Northern blots from N-36/1 cells are presented (Fig. $4 C$ ). These data are the first to suggest that both $\alpha$-MSH and insulin have direct effects on NT neurons and may also play a role in the regulation of energy homeostasis through the NT neuron.

Leptin is an indicator of satiety and is secreted by adipocytes. Because NT has been shown to have anorexigenic effects on in- tracerebroventricular injection into the hypothalamus (Beck et al., 1998), NT-expressing neurons are therefore good candidates for direct regulation by leptin. We were particularly interested in leptin effects on the NT neurons, because evidence exists that NT may mediate the central effects of leptin on feeding behavior (Beck et al., 1998; Sahu et al., 2001). Therefore, the remaining experiments were focused on leptin to understand the mechanisms involved in the regulation of the NT gene in response to leptin. At $4 \mathrm{~h}$, leptin $\left(10^{-11}\right.$ and $\left.10^{-7} \mathrm{M}\right)$ significantly stimulated NT gene expression to 1.5 -fold over the control $(p<0.01 ; n=6)$ in the N-36/1 cell line (Fig. $5 A$ ); however, it had no effect at $10^{-12}$ and $10^{-10}$ to $10^{-8} \mathrm{M}$. Leptin $\left(10^{-11}\right.$ and $\left.10^{-7} \mathrm{M}\right)$ also significantly stimulated NT expression within the N-39 cell line to 1.9and 1.7-fold over the control ( $p<0.05 ; n=6)$, respectively (Fig. $5 B)$. The results in the $\mathrm{N}-36 / 1$ cells were validated using real-time RT-PCR as well (data not shown). Our results confirm those of previous in vivo studies, indicating that leptin directly increases NT expression within the hypothalamus (Sahu, 1998). Intriguingly, the biphasic response of leptin in the NT neurons indicates that there may be different receptors or signaling events involved in this process. Importantly, both clonal cell lines responded with similar expression profiles regardless of the hormonal treatment, indicating that this may be a common mechanism for NT regulation in the hypothalamus.

\section{Localization of leptin responsive region within the NT gene}

To study NT gene regulation by leptin at the transcriptional level, we cloned a region of the 5 ' flanking region of the mouse NT gene onto a luciferase reporter gene, pGL2-enh. The prohormone gene contains coding regions for the two peptides, NT and neurome$\operatorname{din} \mathrm{U}$, and is therefore sometimes referred to as NT/N. The region cloned encompassed -1536 to +173 of the mouse gene. To assess the cis-regulatory sequences necessary for the regulated expression of the mouse NT/N gene in the N-39 neurons, a series of $5^{\prime}$-proximal sequential deletions of this region was further generated and cloned onto the pGL2-enh luciferase reporter gene (Fig. 6A). These constructs were transiently transfected into the N-39 cell line and analyzed for reporter gene activity. Luciferase activity of each construct was compared with that produced by the pGL2-enh alone, the parent vector, which displays negligible promoter activity. Reporter gene activity with the minimal promoter region from +173 to +55 bp was approximately fourfold greater than that of the $\mathrm{pGL} 2$-enh parent vector. A steady increase in reporter gene activity occurs from $-250 /+173$ to $-590 /+173$, indicating that there may be a number of regions necessary for basal expression of the NT gene. The region between -590 and -1521 may contain a repressor region, because basal reporter gene activity was decreased therein. A 1.9-, 1.5-, and 1.7-fold increase in reporter gene activity was observed with $-381 \mathrm{NT}$ LUC, -459 NT-LUC, and -590 NT-LUC after $10^{-7} \mathrm{M}$ leptin treatment, respectively, whereas no statistically significant increase in luciferase activity with - 1521 NT-LUC and -250 NTLUC was detected. These data suggest that the leptin cisregulatory motifs are located within the -381 to -250 bp (131 bp) region (Fig. $6 A$ ).

An alignment of the mouse NT/N gene $5^{\prime}$ flanking sequences (GenBank accession number AF348489) with the corresponding human region (Bean et al., 1992) indicates that the 380 bp region flanking the transcription start site of the human sequences is $72 \%$ identical to the mouse nucleotide sequence. Several regions contain transcription factor binding sites, which are highly conserved between mouse and human (supplemental material, available at www.jneurosci.org). Analysis of the 131 bp region encom- 
passing -381 to -250 of the NT/N 5' regulatory region for known transcription factor consensus binding sites indicated that there was a number of potential binding sites (Fig. 6B) (transcription factor search program Match, BIOBASE Biological Databases). Of particular interest was a series of STAT binding sites $\left[\mathrm{TT}\left(\mathrm{N}_{6}\right)\right.$ $\mathrm{AA}$ ] within -400 of the $5^{\prime}$ flanking region of the NT/N gene (Fig. 6B) (supplemental material, available at www.jneurosci.org). However, this region appears to harbor many putative transcription factor binding sites that may be involved in either basal or leptin-mediated NT gene expression. Specifically, there are potentially eight homeodomain binding sites for Oct-1 or Brn 2 and a number of A-rich regions that can bind Forkhead box (FOX) proteins such as FOXA2 (hepatocyte nuclear factor-3 $\beta$ ) and FOXD3 as well as sites for nuclear factor $\kappa \mathrm{B}$, CCAAT/enhancer binding protein, activator protein 1 (AP-1), and GATA-binding transcription factors (Fig. 6B). There are also cAMP response elements (CREs) and two AP-1 sites located in the proximal promoter region. The conservation of the cisregulatory region reveals that the rodent and human genes are likely to share at least some regulatory properties.

To further understand whether STAT proteins were important for the regulation of the NT gene by leptin, we used wild-type and dominant-negative STAT3 proteins [Y705F (Minami et al., 1996; Muraoka et al., 2003)] cloned into the mammalian expression vector, pEF-Bos, under the control of the elongation factor gene promoter. When we transiently transfected the three constructs into N-39 cells, we found that leptin treatment $\left(10^{-7}\right.$ and $\left.10^{-11} \mathrm{M}\right)$ was able to significantly induce NT gene expression with both the WT-STAT3 and mock pEF-Bos constructs, but NT induction was abolished after transfection of the DN-STAT3 construct (Fig. 7). These results indicate that STAT3 plays a transcriptional role in the regulation of NT gene expression in the N-39 cell line. However, the exact site of action and whether the region within -381 to -250 of the NT gene was necessary remained to be determined.

Chromatin immunoprecipitation assays (ChIPs) were used to determine whether the STAT cis-elements present within the -381 to $-250 \mathrm{bp}$ fragment of the mouse NT/N promoter were active and whether leptin would affect STAT binding to this region. A proven antibody to STAT3 was used to immunoprecipitate the regions bound by the STAT3 transcription factor (Barre et al., 2003, 2005). The ChIP assay demonstrated that STAT3 binds to the -381 to -250 bp region as detected by PCR, using
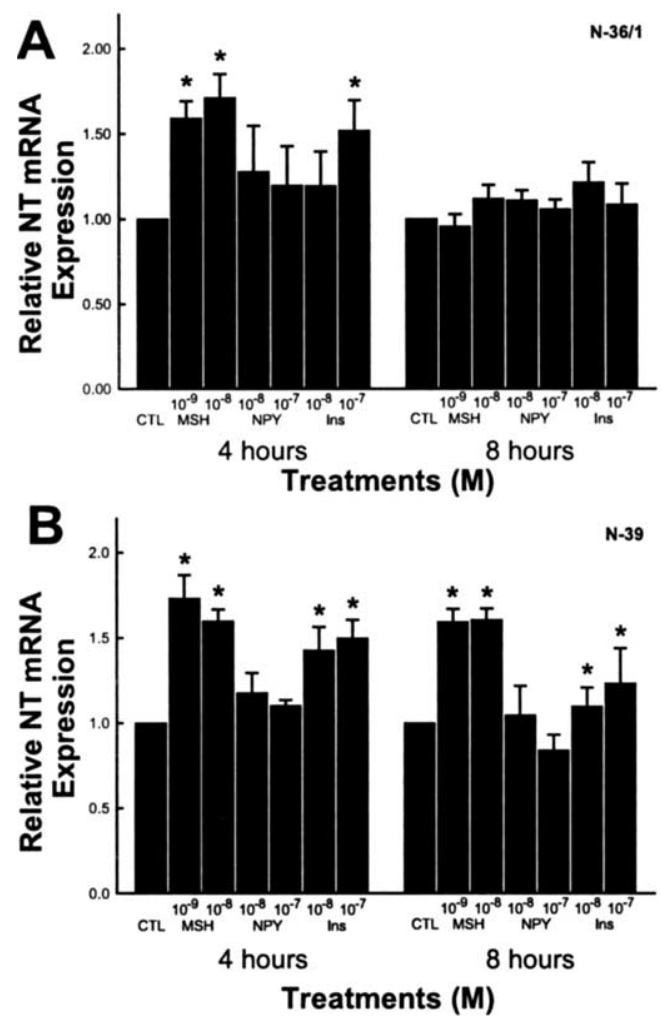

C

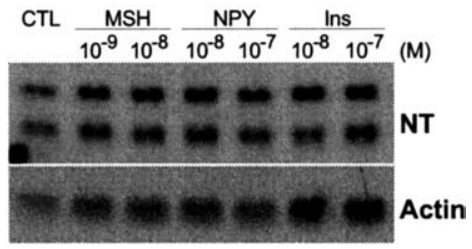

4 hours

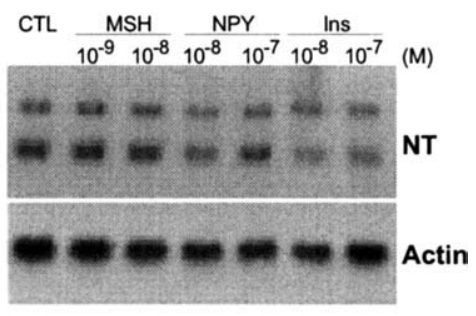

8 hours

Figure 4. NT mRNA expression is regulated by specific peptides in N-36/1 and N-39 neurons. Concentrations of $\alpha$-MSH, NPY, and insulin treatments of N-36/1 and N-39 neurons are indicated. Treatments were for 4 or $8 \mathrm{~h}$ as indicated. The expression of NT mRNA was determined by Northern blot $(\mathrm{N}-36 / 1)(\boldsymbol{A})$ or real-time RT-PCR $(\mathrm{N}-39)(\boldsymbol{B})$. Values for NT are expressed relative to $\beta$-actin mRNA levels (mean $\pm \mathrm{SEM} ; n=3$ ). ${ }^{*} p<0.05$ compared with the untreated control by Student's $t$ test. $C$, Representative Northern blots from N-36/1 total RNA analysis, corresponding to $\boldsymbol{A}$, are shown for both 4 and $8 \mathrm{~h}$ treatments. CTL, Control.
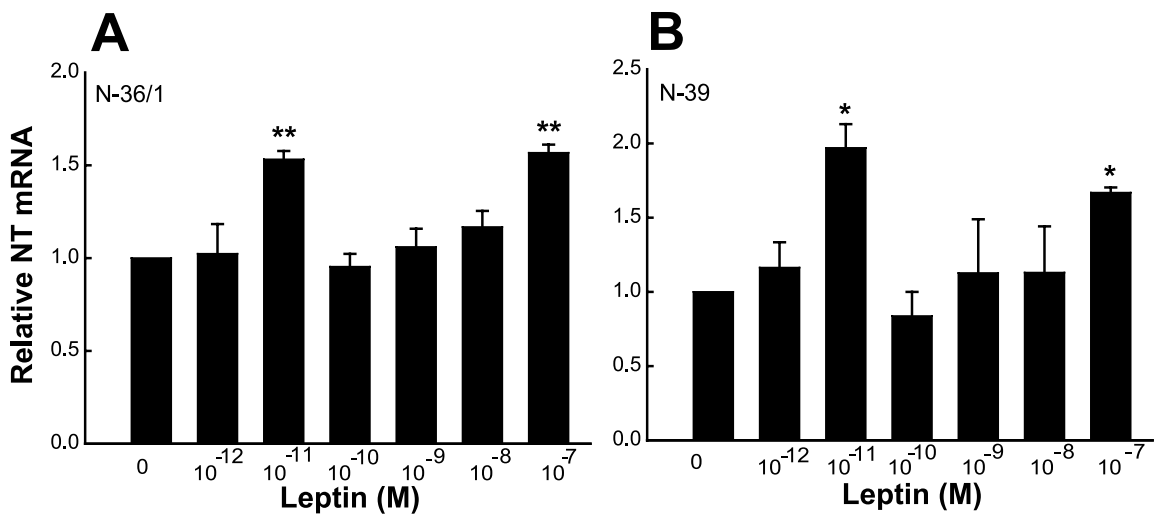

Figure 5. NT mRNA expression is regulated by leptin in N-36/1 and N-39 neurons. Concentrations of leptin treatments of $\mathrm{N}-36 / 1$ and $\mathrm{N}-39$ neurons are indicated. Treatments were for $4 \mathrm{~h}$. The expression of NT mRNA was determined by Northern blot $(\mathrm{N}-313.3 \mathrm{p} 6 / 1)(\boldsymbol{A})$ or real-time RT-PCR (N-39) $(\boldsymbol{B})$. Values for NT are expressed relative to $\beta$-actin mRNA levels (mean \pm SEM; $n=$ 3). ${ }^{*} p<0.05 ;{ }^{* *} p<0.01$, compared with the untreated control by Student's $t$ test.

specific primers to this region of the DNA (Fig. 8). Compared with control, the $10^{-11} \mathrm{M}$ leptin treatment displayed a stronger association of STAT3 to this region than with $10^{-7} \mathrm{M}$ leptin (Fig. 8). PCR analysis of the immunoprecipitation control lacking antibody did not display any amplification of the fragment (Fig. 8, Beads), whereas the preimmunoprecipitation control showed equal amplification of the fragment (Fig. 8, Input). These results indicate that STAT3 binding is necessary for the leptin-mediated transcriptional induction of NT gene expression, specifically at the more physiological levels of leptin exposure. 


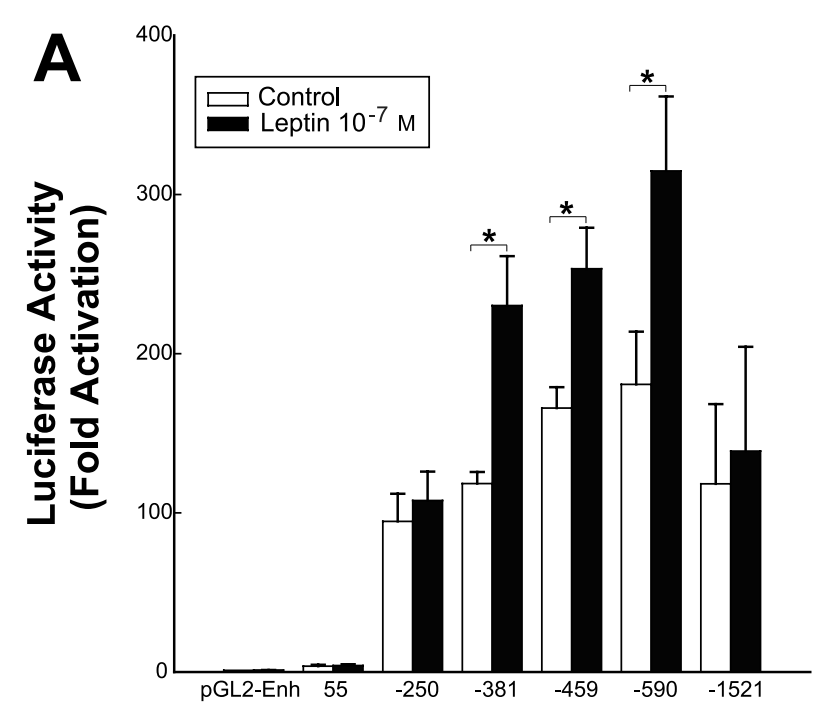

NT/N 5 ' regulatory region deletions

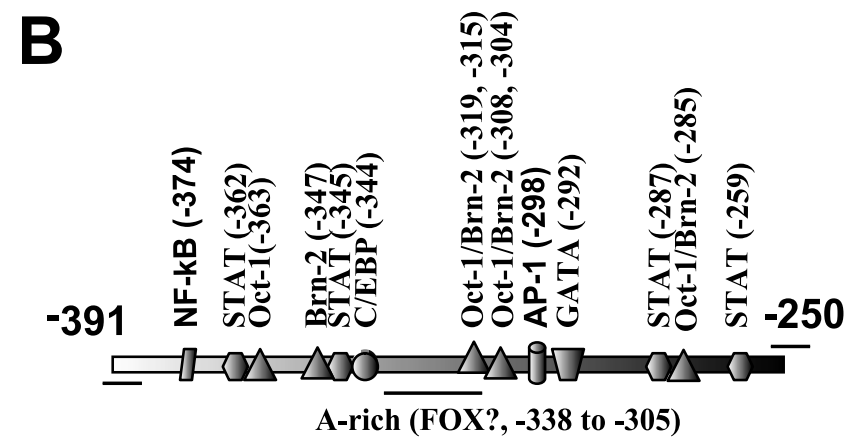

Figure 6. Leptin responsiveness can be mapped to a specific region of the mouse NT 5' regulatory region in $\mathrm{N}-39$ neurons. $\boldsymbol{A}$, The constructs containing indicated lengths of the mouse NT promoter cloned into the promoterless pGL2-enhancer luciferase vector were transiently cotransfected with pCMV $\beta$-galactosidase (internal control) into N-39 cells. After transfection, cells were treated with or without $0.5 \mathrm{~nm}$ leptin for $48 \mathrm{~h}$. Luciferase activity was normalized to $\beta$-galactosidase expression. Each value is expressed as fold-increase relative to $\mathrm{pGL}$-enhancer vector alone. Values are mean \pm SEM from three experiments, each done in triplicate. ${ }^{*} p<$ 0.05 versus untreated. $\boldsymbol{B}$, Diagram of the NT/N promoter region from -381 to -250 . Putative transcription factor binding elements are indicated (as analyzed by Match, BIOBASE Biological Databases), and sequences that were used as oligonucleotide primers in ChIP analysis are underlined.

\section{Discussion}

The hypothalamus has been recognized to play a key role in the regulation of feeding behavior and energy homeostasis, mainly through the ventromedial hypothalamus (VMH), dorsomedial hypothalamus (DMH), lateral hypothalamus (LHA), and arcuate nucleus (ARC). The ARC is currently thought to be the primary site regulated by circulating hormonal inputs, such as leptin or insulin. The ARC also contains the anorexigenic peptides POMC and cocaine and amphetamine-regulated transcript (CART) and the orexigenic peptides NPY and agouti-related protein (AgRP). Both POMC/CART- and NPY/AgRP-containing neurons, in turn, project to other hypothalamic regions, including $\mathrm{VMH}$, $\mathrm{DMH}, \mathrm{LHA}$, and the paraventricular nucleus (PVN) to regulate food intake and energy balance (Chiesi et al., 2001; Barsh and Schwartz, 2002; Berthoud, 2002; Funahashi et al., 2003). In the rat hypothalamus, NT neurons are widely distributed in the ARC, PVN, DMH, and LHA as immunocytochemistry studies have revealed (Kahn et al., 1980; Ibata et al., 1984). Leptin receptors

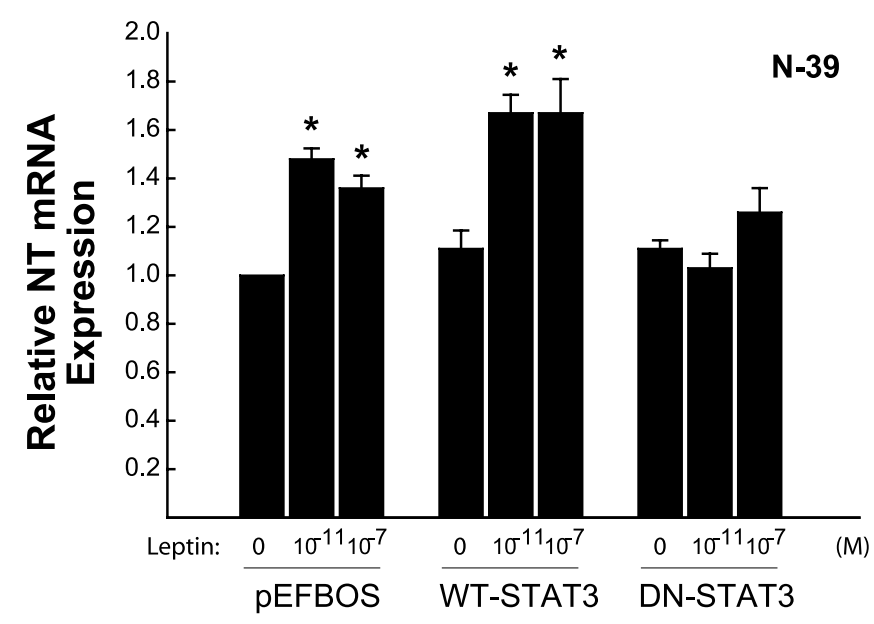

Figure 7. STAT3 is involved in the leptin-mediated induction of NT mRNA expression in N-39 neurons. Cells were transfected with pEFBOS, wild-type (WT) STAT3, or dominant-negative STAT3 (DN-STAT3) for $18 \mathrm{~h}$ and then serum-starved for $2 \mathrm{~h}$ and treated with leptin for $4 \mathrm{~h}$ at the indicated concentrations. The expression of NT mRNA was determined by real-time RT-PCR. Values for NT are expressed relative to $\beta$-actin mRNA levels (mean \pm SEM; $n=4$ ). ${ }^{*} p<0.05$ compared with the untreated control by one-way ANOVA followed by Tukey's multiplecomparison test. M, Molecular mass marker size.

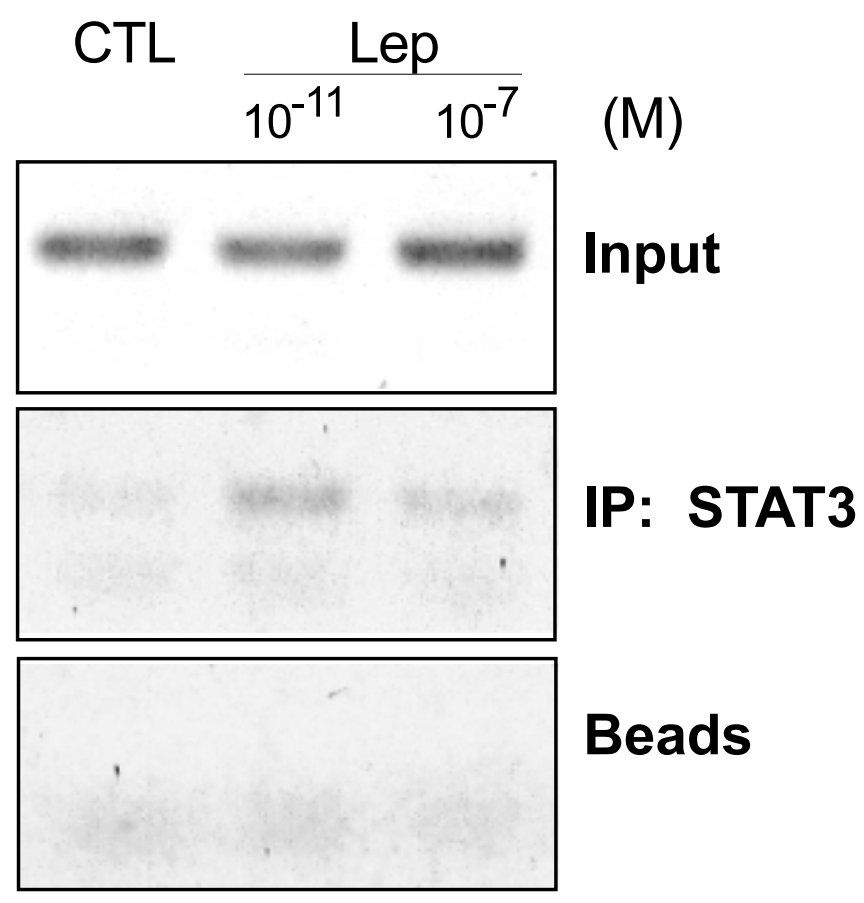

Figure 8. ChIP assays demonstrate that STAT3 binds to the NT/N promoter region. Formaldehyde cross-linked, chromatin-associated DNA from N-39 neurons were immunoprecipitated with an antibody to STAT3. DNA fragments were subjected to PCR amplification using primers flanking the -381 to $-250 \mathrm{bp}$ region of the NT/N promoter. A $130 \mathrm{bp} \mathrm{PCR} \mathrm{product} \mathrm{was}$ observed and sequenced. Negative controls included a no-antibody immunoprecipitation with the protein- $G$ agarose beads (Beads), whereas the positive control consisted of $10 \%$ of the total chromatin in the absence of immunoprecipitation (Input, 50-fold dilution). Representative gel is shown. $n=3$. CTL, Control; Lep, leptin.

$\left(\mathrm{ObR}_{\mathrm{b}}\right)$ are also widely distributed in the ARC, PVN, and LHA (Mercer et al., 1996; Hakansson et al., 1998; Baskin et al., 1999a,b; Elmquist et al., 1999). Therefore, in addition to NPY and POMC neurons, evidence suggests NT neurons are also likely candidates to mediate the effects of leptin.

NT neurons appear to play an anorectic role downstream of 
leptin. Evidence of this is seen in leptin-deficient $o b / o b$ mice (Wilding et al., 1993) or leptin-insensitive $f a / f a$ rats (Beck et al., 1998), in which hypothalamic NT expression is decreased and food intake is reduced. In contrast, intracerebroventricular injection of leptin into the PVN significantly stimulates NT synthesis in association with reduced food intake (Stanley et al., 1983; Beck et al., 1998; Sahu, 1998). Furthermore, immunoneutralization with an NT antibody or an NT receptor antagonist completely reverses the effects of a leptin-induced decrease in food intake (Sahu et al., 2001). These results suggest that leptin action may be mediated, at least in part, by NT. Nevertheless, it is difficult to determine whether the effect of leptin on NT-expressing neurons is direct or through afferent neurons using in vivo studies. To elucidate the direct role of leptin within NT neurons, we screened our cell lines and found that they express the leptin receptor $\left(\mathrm{ObR}_{\mathrm{b}}\right)$. The presence of this receptor indicates that NT neurons are directly influenced by leptin and may play an important role in mediating leptin-induced effects within our cell lines and potentially the hypothalamus.

In addition to the leptin receptor, the N-36/1 and N-39 NT neurons express the $\mathrm{MC}_{4} \mathrm{R}$ receptor, insulin receptor, and NPY receptor. These models will therefore prove valuable to study the activation of endogenous receptor systems in representative hypothalamic cells, not previously feasible because of the lack of cell models inherently expressing the receptor proteins. Treatment with $\alpha-\mathrm{MSH}$ and insulin also stimulates NT gene expression in the NT neurons. To our best knowledge, this is the first report indicating that $\alpha$-MSH or insulin stimulates expression of NT mRNA levels. NPY had no effect on NT gene expression at $4 \mathrm{~h}$; however, these results may reflect the limited time course and concentrations used in this study and will be expanded. Concurrently, we found a significant increase in NT mRNA levels after exposing N-36/1 or N-39 cells to leptin for $4 \mathrm{~h}$. The effect of leptin confirms previous in vivo studies, which suggests that the $\mathrm{ObR}_{\mathrm{b}}$ is involved in the regulation of NT synthesis by leptin. In addition, our results demonstrate the necessity of the STAT3 transcription factor in leptin-mediated induction of NT. It has been reported that leptin induces expression of TRH in PVN neurons of the hypothalamus and that the TRH gene promoter is directly regulated by leptin signaling through binding of STAT3 and cAMP responsive element binding proteins (Harris et al., 2001). Previous analysis of the NT gene indicates that synergistic activation of AP-1 and CRE motifs play an important functional role in hormonal regulation of NT gene expression (Harrison et al., 1995). It is particularly compelling to speculate that these sites may also be involved in the leptin-mediated control of NT gene expression, because there are multiple sites for these transcription factors within the pertinent -381 to -250 responsive region of the NT gene. Together, this evidence strongly suggests that NT may mediate, in part, anorectic action in the hypothalamus and that NT neurons can potentially act as first-order neurons directly regulated by leptin.

Most of the in vitro signal transduction experiments in specific cell lines show that $0.62-100 \mathrm{~nm}$ leptin induces signal transduction (Kellerer et al., 1997; Bjorbaek et al., 1999, 2001; Li and Friedman, 1999). However, these cell lines may not respond appropriately to physiological levels of leptin, because transfection of the $\mathrm{Ob}-\mathrm{R}_{\mathrm{b}}$ was necessary. Although these studies effectively began to elucidate the mechanisms of leptin signaling, the N-36/1 and $\mathrm{N}-39$ cells express the Ob- $\mathrm{R}_{\mathrm{b}}$ endogenously and show a definite response to physiological concentrations of leptin. In vivo studies have shown a physiological response at low concentrations of leptin, such as that seen during fasting (Ahima et al.,
1996). In humans, plasma leptin concentrations range from $\sim 0.5$ to $2.5 \mathrm{~nm}$ in lean and obese people, respectively. However, in the CSF of obese subjects, leptin concentrations are $\sim 0.02 \mathrm{nM}$, only $30 \%$ higher than in lean subjects. These findings suggest that leptin transport into the brain is through a saturable transport carrier (Caro et al., 1996; Schwartz et al., 1996). Our in vitro experiments indicate that NT neurons show a biphasic response to leptin at $10^{-11} \mathrm{M}(0.01 \mathrm{nM})$ and $10^{-7} \mathrm{M}(100 \mathrm{nM})$ concentrations. We suggest that the response to low-dose leptin is typical of normal physiology. However, it is possible that the response to $10^{-7} \mathrm{M}$ is a result of altered leptin signaling at supraphysiological levels of leptin. The major hypothalamic pathway of leptin signaling is the JAK2-STAT3 pathway. Leptin induces phosphorylation of STAT molecules within the hypothalamus (McCowen et al., 1998). STAT3 is one of the major intracellular mediators of leptin signaling within neurons expressing POMC, NPY, melanin-concentrating hormone, orexin, and galanin (Sahu, 2003). Through chromatin precipitation studies, we found that STAT3 binding is induced at low levels of leptin $\left(10^{-11} \mathrm{M}\right)$ but is not significantly different from control at $10^{-7} \mathrm{M}$. This suggests that another signaling pathway may be involved in mediating the induction of NT mRNA in response to leptin at this concentration. It is now recognized that leptin receptor activation can induce the mitogen-activated protein (MAP) kinase/extracellular signal-regulated kinase (ERK) (Banks et al., 2000) and phosphatidyl inositol 3-kinase (PI3K)/Akt (Niswender and Schwartz, 2003) pathways. Although leptin has been postulated to signal mainly through the JAK-STAT signal transduction pathway, a knockout mouse that leaves the leptin receptor intact but specifically disrupts the ObR-STAT3 signal (leprS1138) does not affect repression of NPY by leptin nor reproductive function (Bates et al., 2003). This suggests that there is a STAT3-independent pathway, specifically used to control NPY neuron responsiveness to leptin (Bates et al., 2003), which may also mediate the response seen with NT. Alternatively, high levels of leptin may disrupt the signaling machinery leading to a response similar to the leptin resistance seen in vivo. Several authors suggest that defective leptin signaling, through attenuated STAT3 (El-Haschimi et al., 2000) or increased suppressors of cytokine signaling-3 (SOCS-3) (Munzberg et al., 2004), may contribute to leptin resistance. Leptin resistance is hypothesized to be a result of increased SOCS-3 levels, which are elevated by leptin administration. SOCS-3 itself is an inhibitor of leptin signaling (Bjorbaek et al., 1999), but a low concentration of leptin may not induce effective inhibitory levels of the SOCS-3 protein. Therefore, leptin may induce differential signal transduction pathways and effector molecules at physiological versus supraphysiological concentrations.

We are currently defining the alternative signal transduction pathways (PI3K/Akt and MAPK/Erk1/2) activated by the varying concentrations of leptin within the N-36/1 and N-39 NT neuronal cell models to elucidate their differential roles in leptininduced NT expression. We will further define the molecular mechanisms involved in the leptin-mediated control of NT neurons in the hypothalamus using our clonal NT-expressing cell models. The studies herein provide convincing evidence that NT neurons are directly regulated by leptin, $\alpha-\mathrm{MSH}$, and insulin and therefore may indeed be a first-order neuron involved in the control of energy homeostasis.

\section{References}

Ahima RS, Prabakaran D, Mantzoros C, Qu D, Lowell B, Maratos-Flier E, Flier JS (1996) Role of leptin in the neuroendocrine response to fasting. Nature 382:250-252. 
Banks AS, Davis SM, Bates SH, Myers Jr MG (2000) Activation of downstream signals by the long form of the leptin receptor. J Biol Chem 275:14563-14572.

Barre B, Avril S, Coqueret O (2003) Opposite regulation of myc and p21waf1 transcription by STAT3 proteins. J Biol Chem 278:2990-2996.

Barre B, Vigneron A, Coqueret O (2005) The STAT3 transcription factor is a target for the Myc and riboblastoma proteins on the $\mathrm{Cdc} 25 \mathrm{~A}$ promoter. J Biol Chem 280:15673-15681.

Barsh GS, Schwartz MW (2002) Genetic approaches to studying energy balance: perception and integration. Nat Rev Genet 3:589-600.

Baskin DG, Hahn TM, Schwartz MW (1999a) Leptin sensitive neurons in the hypothalamus. Horm Metab Res 31:345-350.

Baskin DG, Schwartz MW, Seeley RJ, Woods SC, Porte Jr D, Breininger JF, Jonak Z, Schaefer J, Krouse M, Burghardt C, Campfield LA, Burn P, Kochan JP (1999b) Leptin receptor long-form splice-variant protein expression in neuron cell bodies of the brain and co-localization with neuropeptide $\mathrm{Y}$ mRNA in the arcuate nucleus. J Histochem Cytochem 47:353-362.

Bates SH, Stearns WH, Dundon TA, Schubert M, Tso AW, Wang Y, Banks AS, Lavery HJ, Haq AK, Maratos-Flier E, Neel BG, Schwartz MW, Myers MG (2003) STAT3 signalling is required for leptin regulation of energy balance but not reproduction. Nature 421:856-859.

Bean AJ, Dagerlind A, Hokfelt T, Dobner PR (1992) Cloning of human neurotensin/neuromedin $\mathrm{N}$ genomic sequences and expression in the ventral mesencephalon of schizophrenics and age/sex matched controls. Neuroscience 50:259-268.

Beck B, Stricker-Krongrad A, Richy S, Burlet C (1998) Evidence that hypothalamic neurotensin signals leptin effects on feeding behavior in normal and fat-preferring rats. Biochem Biophys Res Commun 252:634-638.

Belsham DD, Wetsel WC, Mellon PL (1996) NMDA and nitric oxide act through the cGMP signal transduction pathway to repress hypothalamic gonadotropin-releasing hormone gene expression. EMBO J 15:538-547.

Belsham DD, Evangelou A, Roy D, Le D, Brown TJ (1998) Regulation of gonadotropin-releasing hormone gene expression by 5adihydrotestosterone in GnRH-secreting GT1-7 hypothalamic neurons. Endocrinology 139:1108-1114.

Belsham DD, Cai F, Cui H, Smukler SR, Salapatek AMF, Shkreta L (2004) Generation of a phenotypic array of hypothalamic neuronal cell models to study complex neuroendocrine disorders. Endocrinology 145:393-400.

Berthoud HR (2002) Multiple neural systems controlling food intake and body weight. Neurosci Biobehav Rev 26:393-428.

Bjorbaek C, El-Haschimi K, Frantz JD, Flier JS (1999) The role of SOCS-3 in leptin signaling and leptin resistance. J Biol Chem 274:30059-30065.

Bjorbaek C, Buchholz RM, Davis SM, Bates SH, Pierroz DD, Gu H, Neel BG, Myers Jr MG, Flier JS (2001) Divergent roles of SHP-2 in ERK activation by leptin receptors. J Biol Chem 276:4747-4755.

Brown M, McCormack M, Zinn KG, Farrell MP, Bikel I, Livingston DM (1986) A recombinant murine retrovirus for simian virus 40 large $T$ cDNA transforms mouse fibroblasts to anchorage-independent growth. J Virol 60:290-293.

Caro JF, Kolaczynski JW, Nyce MR, Ohannesian JP, Opentanova I, Goldman WH, Lynn RB, Zhang PL, Sinha MK, Considine RV (1996) Decreased cerebrospinal-fluid/serum leptin ratio in obesity: a possible mechanism for leptin resistance. Lancet 348:159-161.

Carraway R, Leeman SE (1973) The isolation of a new hypotensive peptide, neurotensin, from bovine hypothalami. J Biol Chem 248:6854-6861.

Carraway R, Leeman SE (1975) The amino acid sequence of a hypothalamic peptide, neurotensin. J Biol Chem 250:1907-1911.

Chiesi M, Huppertz C, Hofbauer KG (2001) Pharmacotherapy of obesity: targets and perspectives. Trends Pharmacol Sci 22:247-254.

Chomczynski P, Sacchi N (1987) Single-step method of RNA isolation by acid guanidinium thiocyanate-phenol-chloroform extraction. Anal Biochem 162:156-159.

Dobner PR, Fadel J, Deitemeyer N, Carraway RE, Deutch AY (2001) Neurotensin-deficient mice show altered responses to antipsychotic drugs. Proc Natl Acad Sci USA 98:8048-8053.

El-Haschimi K, Pierroz DD, Hileman SM, Bjorbaek C, Flier JS (2000) Two defects contribute to hypothalamic leptin resistance in mice with dietinduced obesity. J Clin Invest 105:1827-1832.

Elias CF, Aschkenasi C, Lee C, Kelly J, Ahima RS, Bjorbaek C, Flier JS, Saper CB, Elmquist JK (1999) Leptin differentially regulates NPY and POMC neurons projecting to the lateral hypothalamic area. Neuron 23:775-786.
Elias CF, Kelly JF, Lee CE, Ahima RS, Drucker DJ, Saper CB, Elmquist JK (2000) Chemical characterization of leptin-activated neurons in the rat brain. J Comp Neurol 423:261-281.

Elmquist JK, Elias CF, Saper CB (1999) From lesions to leptin: hypothalamic control of food intake and body weight. Neuron 22:221-232.

Funahashi H, Takenoya F, Guan JL, Kageyama H, Yada T, Shioda S (2003) Hypothalamic neuronal networks and feeding-related peptides involved in the regulation of feeding. Anat Sci Int 78:123-138.

Ghilardi N, Ziegler S, Wiestner A, Stoffel R, Heim MH, Skoda RC (1996) Defective STAT signaling by the leptin receptor in diabetic mice. Proc Natl Acad Sci USA 93:6231-6235.

Hakansson ML, Brown H, Ghilardi N, Skoda RC, Meister B (1998) Leptin receptor immunoreactivity in chemically defined target neurons of the hypothalamus. J Neurosci 18:559-572.

Harris M, Aschkenasi C, Elias CF, Chandrankunnel A, Nillni EA, Bjoorbaek C, Elmquist JK, Flier JS, Hollenberg AN (2001) Transcriptional regulation of the thyrotropin-releasing hormone gene by leptin and melanocortin signaling. J Clin Invest 107:111-120.

Harrison RJ, McNeil GP, Dobner PR (1995) Synergistic activation of neurotensin/neuromedin $\mathrm{N}$ gene expression by c-Jun and glucocorticoids: novel effects of Fos family proteins. Mol Endocrinol 9:981-993.

Ibata Y, Kawakami F, Fukui K, Obata-Tsuto HL, Tanaka M, Kubo T, Okamura H, Morimoto N, Yanaihara C, Yanaihara N (1984) Light and electron microscopic immunocytochemistry of neurotensin-like immunoreactive neurons in the rat hypothalamus. Brain Res 302:221-230.

Kahn D, Abrams GM, Zimmerman EA, Carraway R, Leeman SE (1980) Neurotensin neurons in the rat hypothalamus: an immunocytochemical study. Endocrinology 107:47-54.

Kellerer M, Koch M, Metzinger E, Mushack J, Capp E, Haring HU (1997) Leptin activates PI-3 kinase in C2C12 myotubes via janus kinase-2 (JAK-2) and insulin receptor substrate-2 (IRS-2) dependent pathways. Diabetologia 40:1358-1362.

Lee GH, Proenca R, Montez JM, Carroll KM, Darvishzadeh JG, Lee JI, Friedman JM (1996) Abnormal splicing of the leptin receptor in diabetic mice. Nature 379:632-635.

Li C, Friedman JM (1999) Leptin receptor activation of SH2 domain containing protein tyrosine phosphatase 2 modulates $\mathrm{Ob}$ receptor signal transduction. Proc Natl Acad Sci USA 96:9677-9682.

Maniatis T, Fritsch EF, Sambrook J (1982) Molecular cloning: a laboratory manual. New York: Cold Spring Harbor Laboratory.

Mazella J, Zsurger N, Navarro V, Chabry J, Kaghad M, Caput D, Ferrara P, Vita N, Gully D, Maffrand JP, Vincent JP (1998) The 100-kDa neurotensin receptor is gp95/sortilin, a non-G-protein-coupled receptor. J Biol Chem 273:26273-26276.

McCowen KC, Chow JC, Smith RJ (1998) Leptin signaling in the hypothalamus of normal rats in vivo. Endocrinology 139:4442-4447.

Mellon PL, Parker V, Gluzman Y, Maniatis T (1981) Identification of DNA sequences required for transcription of the human alpha ${ }_{1}$ globin gene using a new SV40 host-vector system. Cell 27:279-288.

Mercer JG, Hoggard N, Williams LM, Lawrence CB, Hannah LT, Trayhurn P (1996) Localization of leptin receptor mRNA and the long form splice variant $(\mathrm{Ob}-\mathrm{Rb})$ in mouse hypothalamus and adjacent brain regions by in situ hybridization. FEBS Lett 387:113-116.

Meyer-Spasche A, Reed HE, Piggins HD (2002) Neurotensin phase-shifts the firing rate rhythm of neurons in the rat suprachiasmatic nuclei in vitro. Eur J Neurosci 16:339-344.

Minami M, Inoue M, Wei S, Takeda K, Matsumoto M, Kishimoto T, Akira S (1996) STAT3 activation is a critical step in gp130-mediated terminal differentiation and growth arrest of a myeloid cell line. Proc Natl Acad Sci USA 93:3963-3966.

Munzberg H, Flier JS, Bjorbaek C (2004) Region-specific leptin resistance within the hypothalamus of diet-induced obese mice. Endocrinology 145:4880-4889.

Muraoka O, Xu B, Tsurumaki T, Akira S, Yamaguchi T, Higuchi H (2003) Leptin-induced transactivation of NPY gene promoter mediated by JAK1, JAK2 and STAT3 in the neural cell lines. Neurochem Int 42:591-601.

Niswender KD, Schwartz MW (2003) Insulin and leptin revisited: adiposity signals with overlapping physiological and intracellular signaling capabilities. Front Neuroendocrinol 24:1-10.

Remaury A, Vita N, Gendreau S, Jung M, Arnone M, Poncelet M, Culouscou JM, Le Fur G, Soubrie P, Caput D, Shire D, Kopf M, Ferrara P (2002) Targeted inactivation of the neurotensin type 1 receptor reveals its role in 
body temperature control and feeding behavior but not in analgesia. Brain Res 953:63-72.

Richy S, Burlet A, Max J, Burlet C, Beck B (2000) Effect of chronic intraperitoneal injections of leptin on hypothalamic neurotensin content and food intake. Brain Res 862:276-279.

Rostene WH, Alexander MJ (1997) Neurotensin and neuroendocrine regulation. Front Neuroendocrinol 18:115-173.

Sahu A (1998) Evidence suggesting that galanin (GAL), melaninconcentrating hormone $(\mathrm{MCH})$, neurotensin $(\mathrm{NT})$, proopiomelanocortin (POMC) and neuropeptide $\mathrm{Y}$ (NPY) are targets of leptin signaling in the hypothalamus. Endocrinology 139:795-798.

Sahu A (2003) Leptin signaling in the hypothalamus: emphasis on energy homeostasis and leptin resistance. Front Neuroendocrinol 24:225-253.

Sahu A, Carraway RE, Wang YP (2001) Evidence that neurotensin mediates the central effect of leptin on food intake in rat. Brain Res 888:343-347.

Schwartz MW, Peskind E, Raskind M, Boyko EJ, Porte Jr D (1996) Cerebrospinal fluid leptin levels: relationship to plasma levels and to adiposity in humans. Nat Med 2:589-593.

Schwartz MW, Baskin DG, Kaiyala KJ, Woods SC (1999) Model for the regulation of energy balance and adiposity by the central nervous system. Am J Clin Nutr 69:584-596.
Stanley BG, Hoebel BG, Leibowitz SF (1983) Neurotensin: effects of hypothalamic and intravenous injections on eating and drinking in rats. Peptides 4:493-500.

Tartaglia LA, Dembski M, Weng X, Deng N, Culpepper J, Devos R, Richards GJ, Campfield LA, Clark FT, Deeds J, Muir C, Sanker S, Moriarty A, Moore KJ, Smutko JS, Mays GG, Wool EA, Monroe CA, Tepper RI (1995) Identification and expression cloning of a leptin receptor, OB-R. Cell 83:1263-1271.

Tyler-McMahon BM, Boules M, Richelson E (2000) Neurotensin: peptide for the next millennium. Regul Pept 93:125-136.

Watters JJ, Dorsa DM (1998) Transcriptional effects of estrogen on neuronal neurotensin gene expression involve cAMP/protein kinase A-dependent signaling mechanisms. J Neurosci 18:6672-6680.

Wilding JP, Gilbey SG, Bailey CJ, Batt RA, Williams G, Ghatei MA, Bloom SR (1993) Increased neuropeptide-Y messenger ribonucleic acid (mRNA) and decreased neurotensin mRNA in the hypothalamus of the obese (ob/ ob) mouse. Endocrinology 132:1939-1944.

Zhang Y, Proenca R, Maffei M, Barone M, Leopold L, Friedman JM (1994) Positional cloning of the mouse obese gene and its human homologue. Nature 372:425-432. 